\title{
ERRATUM
}

\section{Erratum to: Reproductive tactics of the freshwater fish Brycon guatemalensis (Teleostei: characidae) in the lake Nicaragua}

\author{
Aldo Hernández-Portocarrero • \\ Rosario Domínguez-Petit • Fran Saborido-Rey
}

Published online: 24 April 2015

(C) Springer Science+Business Media Dordrecht 2015

Erratum to: Environ Biol Fish (2015) 98:535-546

DOI 10.1007/s10641-014-0285-0

The name of Professor Fran Saborido-Rey is incorrect in the original version of the paper. His name is now corrected in the list of authors and in the affiliation field.

The online version of the original article can be found at http:// dx.doi:10.1007/s10641-014-0285-0.

The online version of the original article can be found at http://dx. doi.org/10.1007/s10641-014-0285-0.

A. Hernández-Portocarrero $(\bowtie) \cdot R$. Domínguez-Petit • F. Saborido-Rey

Instituto de Investigaciones Marinas (IIM-CSIC), C/Eduardo

Cabello 6, Vigo, Pontevedra 36208, Spain

e-mail: aldoherpo@yahoo.com.ni 